\title{
Biçim Oluşma Etkenleri Bakımından Amsterdam Stedelijk Müzesi
}

\section{Amsterdam Stedelijk Museum in Terms of Formation Factors}

\author{
Ersan YILDIZ ${ }^{a *} \theta$ (i), Münevver DAĞGÜLÜ ${ }^{b} \theta$ ic
}

a Öğr. Gör., Yıldız Teknik Üniversitesi, Mimarlık ve Tasarım Fakültesi, Mimarlık Bölümü, İstanbul, 34349, Türkiye b Dr. Öğr. Üyesi., Yıldız Teknik Üniversitesi, Mimarlık ve Tasarım Fakültesi, Mimarlık Bölümü, İstanbul, 34349 , Türkiye Article history: Received 06.02.2021 / Accepted 24.06.2021

\section{ÖZET}

Bütünü oluşturan elamanların tutarlı bir biçime imkân vermesi için koordinasyon ve kurgu ile bir yapı oluşturulur. Biçim nesnelerin siluetini yapılandıran etkendir. Binaların sahip olduğu biçimler, ayrıştırıcı tasarım özelliklerini meydana getiren maddi ögelerin kurgusu ile meydana gelir. Mimarlık dünyası içinde biçim, bir yapıyı oluşturan mekanların ve kabuğun sınırlarını ifade eden bir kavram olmaktan fazlasıdır. Algılanan şekil, renk ve dokudan fazlasını, tüm unsurların organik birlikteliğini ve uyumunu ifade eder. Amaç: Çeşitli ögelerin, farklı bağlamlar içerisinde bir araya gelerek benzersiz birleşimler olarak meydana getirdiği biçimlerin üretilmesinde rol oynayan etkenlerden hangilerinin Stedelijk Müzesi ek yapısının biçim oluşumunda rol aldığı tespit edilmiştir. Yöntem: Arazi çalışması ve yapılan kaynak incelemeleri ile ortaya konan kriterler doğrultusunda, Stedelijk Müzesi ek yapısının biçim oluşumunda rol alan etkenler değerlendirilmiştir. Bulgular: Stedelijk Müzesi ek yapısı tasarımını oluşturan biçimlenişin ardında pek çok etmen birbirleriyle bağlantıdır. Sonuç: Tasarım sürecinde etmenler arası ilişkiler kurgulanırken yapıya yüklenen prestij ve anlam ilk sırada yer alırken birbirinden farklı etmenler öncelikli roller üstlenmiştir. Yapı örneğinde tespit edilen etmenler arasında farklı düzeyde önem sıralamasının olduğu ortaya koyulmuştur.

Anahtar Kelimeler: Stedelijk Müzesi, Biçim, Biçimlenme Etkenleri

\section{ABSTRACT}

A structure is created with coordination and fiction so that the elements that make up the whole allow a consistent form. Form is what constructs the silhouette of objects. The forms of buildings are formed by the fiction of material elements that create distinctive design features. In the world of architecture, form is more than a concept that expresses the boundaries of the spaces and the shell that form a building. It expresses more than the perceived shape, color and texture, the organic unity and harmony of all elements. Aim: It has been determined which factors that play a role in the production of forms formed by various elements in different contexts as unique combinations play a role in the formation of the Stedelijk Museum annex structure. Method: In line with the criteria determined by field study and source studies, the factors involved in the formation of the form of the Stedelijk Museum additional structure were evaluated. Findings: Many factors behind the formation of the annex building design of the Stedelijk Museum are interconnected. Conclusion: In the design process, while constructing relations between factors, prestige and meaning ascribed to the structure took the first place, while different factors played primary roles. It has been revealed that among the factors determined in the building sample, there is a different order of importance.

Keywords: Stedelijk Museum, Form, Formation Factors

\section{GİRIŞ}

Büyük Larousse (1986) tarafından "bir nesnenin çevre çizgilerinin düzeni, görünümü, şekli" olarak tanımlanan biçim kavramı Türk Dil Kurumu tarafından hazırlanan Türkçe Sözlük (Akalın, I. ve Halık, 2011) içerisinde "bir nesnenin dış çizgileri bakımından niteliği, dıştan görünüşü, şekil, eşkal" şeklinde açıklanır. Kavramın yabancı literatürde kullanımında karşılaştığımız İngilizce "form" ve Fransızca "forme" kelimeleri, şekil, biçim, görünüş anlamlarını içeren Latince "forma" kelimesinden türemiş olup aynı anlamı taşımaktadır. Hasol (2016) kavramı "somut sanatlarda belli bir temanın plastik veya grafik açıdan dile getirilişi" olarak tanımlar. Hasol'a göre tasarım sürecinde aktarılmak istenen konuyu grafik yöntemler ile dile getirirken biçimlerden faydalanılır. Düzgün (2013) ise mimarlık faaliyetleri içerisinde mimari yapıyı oluşturan mekanların şekli, yapının sahip olduğu kitlesi veya bütünün yapısını biçim olarak tanımlar.

"Architecture: Form, Space, and Order" isimli kitabı ile konu üzerindeki araştırma ve tespitlerini paylaşan Ching'e (2016) göre iç ve dış yapı tasarlanırken bütünün kendinde hissedilen birlik düşüncesi oluşturulur. Bütünü oluşturan elamanların tutarlı bir imgeye imkân vermesi için koordinasyon ve kurgu ile biçimsel yapı oluşturulur. Crisman (2007) biçimi nesnelerin siluetini yapılandıran etken olarak açıklar. Mimarlık yapıtının sahip olduğu biçimler,

* Corresponding author.

http://dx.doi.org/10.16950/iujad.881608 
onun ayrıştırıcı tasarım özelliklerini meydana getiren maddi ögelerin kurgusu ile meydana gelir (İzgi, 1999). Shahn (1957) için biçim aslında tasarım nesnesinin taşıdığı içeriğin görünen yüzü olurken biçim ile içerik arasında ayrılmaz bir ilişki mevcuttur.

Mimarlığın temel uğraşı olan mekân tasarımında hedef mimarlık nesnesini biçimlendirmektir (Ersal, 2013). Giaccardi ve Fischer (2008) tasarım faaliyetlerini belli kurallar içerisinde devam eden, problem çözmeyi hedefleyen bir süreç olarak tanımlar. Bünyesinde araştırma adımlarını da barındıran bu süreç, hedef problemi tanımlamakla birlikte bu probleme karşı yaratıcı ve makul çözümler bulmak amacını da taşır.

Alexander (1964), tasarım süreci sonunda aslında tek bir hedefin var olduğunu, bu hedefin de biçimin kendisi olduğunu belirtir. Belirlenen probleme cevap vermesi beklenen, tasarım sonucu ortaya konan biçimlenmenin aynı zamanda estetik değer içermesi istenir. Bir tasarım problemi olan mimarlık Mitchell'e (1990) göre tasarlanan yapının işlevi ile biçimi arasındaki ilişkidir.

Biçim ve mekân arasındaki ilişkiye değinen Bacon'a (1974) göre kütle ile mekânın temas ettiği noktada biçim meydana gelmektedir. Mimari tasarım faaliyetleri içerisinde biçim, mekanların birlikteliği ile ortaya bir dışsal şekil oluşturulması düşüncesinden fazlasını içerir. Norman ve Varver' e (1999) göre biçim kelimesi mimarlık faaliyetleri içerisinde tutarlı bir bütün oluşturan öğelerin birlik ve uyumunu ima eder. Biçimler boyut, renk, doku gibi görsel özellik katan öğelerle ve düzenlemenin yerleşim, yönelim gibi özelliklerin bir araya gelmesi ile oluşur. Bu oluşum düzenli ve düzensiz olmak üzere gruplanarak incelenebilmektedir (Ching, 2016). Genellikle bir veya daha fazla eksende simetrik oluşumlar ile düzenli biçimler üretilirken birbirini tekrar etmeyen düzensiz biçimlendirmeler ise genellikle asimetrik ve dinamik yapılandırmalar olarak var olurlar. Düzenli veya düzensiz olarak tanımlanacak biçimlendirmelere geometrik anlamları dışında farklı anlamlar yüklenebilmektedir (Demirkaya, 2003). Çeşitli kavramları işaret eden biçimlendirmeleri tercih eden mimarların bu kullanım tercihleri, kişisel veya dönemsel üslupların meydana gelmesinde belirleyici olmuştur. Elaver (2012), ürün veya mekân kimliğinin kültürel bağlamda oluşan anlamların iletişimi ile biçimin oluştuğuna dikkat çeker. İnsanların veya toplumların sahip oldukları duygu, düşünce ve eğilimlerin bireyler ve toplumlar arasında kuşaklar boyunca iletilmesini sağlayan bir anlatım aracı olarak biçimlendirme etkinliği, iletişim aracı görevi görür (Düzgün, 2013).

Onat (2010), biçimlendirmeleri mimari bir nesnenin sürekliliğini ve sınırlarını belirleyen düzen olarak tanımlar. Farklı problemlere çözümler getiren tasarımcının sahip olduğu öznellikler, bu sürecin çok farklı yöntem, düzen ve yaklaşımlar ile oluşturmasına olanak verir (Broadbent, 1973; Uraz, 1993).

Tasarım faaliyetine bağlı olarak oluşturulan biçimlerin temel ögeleri, yapının kitlesi, kurgulanan mekanlar ve oluşturulan yüzeylerdir. Yapının aslında ne olduğunu ve yaratılış amacı açısından sahip olduğu şekilsel ve çevresel ilişkiler aracılığı ile tanımlanabilen biçimler (Kıran ve Polatoğlu, 2011) günümüzde nesnel veya öznel, fiziksel veya fiziksel olmayan, yapısal veya deneysel ögelerin meydana getirdiği benzersiz birleşimler olarak var olurlar (Moussavi, 2011).

Çeşitli ögelerin farklı bağlamlar içerisinde bir araya gelerek benzersiz birleşimler olarak meydana getirdiği biçimlerin üretilmesinde rol oynayan pek çok etmen bulunmaktadır. Mimarlıkta yapıların sahip olduğu biçimlerin oluşmasında gözlemlenen etkenleri Tablo $1^{\prime}$ de göründüğü gibi gruplamak mümkündür (İ. Dağgülü ve M. Dağgülü, 2019). Yapının yerleştiği bölgenin çevresel özelliklerine, tasarımcının sahip olduğu değer ve düşünce düzeyine, toplumsal kabul ve yerleşik değerler sistemine ve son olarak teknolojik gelişmelere bağlı gruplanan etmenlerin yapının biçimlenme sürecinde çoklu olarak bir araya gelmeleri ve farklı biçimlenmelere imkân vermeleri mümkündür (Etike ve Dağgülü 2019).

Tablo 1. Biçime etki eden faktörlerin gruplandırılması (İ. Dağgülü ve M. Dağgülü yayınlanmamış ders notlarından uyarlanarak oluşturulmuştur.) 


\begin{tabular}{|c|c|c|c|c|c|}
\hline \multirow{2}{*}{$\begin{array}{l}\text { Çevresel } \\
\text { Etmenler }\end{array}$} & İklim & $\begin{array}{c}\text { Çevreden } \\
\text { Sağlanabilen } \\
\text { Doğal Yapı } \\
\text { Malzemeleri }\end{array}$ & $\begin{array}{l}\text { Zemin Özelliği } \\
\text { ve Deprem } \\
\text { Faktörü }\end{array}$ & & \\
\hline & Topoğrafya & Yapay Çevre & $\begin{array}{c}\text { Manzara ve } \\
\text { Uygun } \\
\text { Yönelme }\end{array}$ & & \\
\hline \multirow{2}{*}{$\begin{array}{l}\text { Tasarımcının } \\
\text { Sahip Olduğu } \\
\text { Değer ve } \\
\text { Düşünce } \\
\text { Düzeyine } \\
\text { Bağlı } \\
\text { Etmenler }\end{array}$} & Akımlar & $\begin{array}{l}\text { Çevresel } \\
\text { Odaklı } \\
\text { Tasarım } \\
\text { Düşüncesi }\end{array}$ & $\begin{array}{c}\text { Dikkat } \\
\text { Cekmek, } \\
\text { Şaşırtmak }\end{array}$ & & \\
\hline & $\begin{array}{c}\text { Biçim ve Yer } \\
\text { Deăiștirebilme } \\
\text { Yeteneği } \\
\text { Arayışları }\end{array}$ & İşlevsellik & $\begin{array}{c}\text { Tasarım } \\
\text { Yaklașımları }\end{array}$ & & \\
\hline \multirow{2}{*}{$\begin{array}{l}\text { Toplumsal } \\
\text { Kabul ve } \\
\text { Yerleșik } \\
\text { Değerler } \\
\text { Sistemine } \\
\text { Bağlı } \\
\text { Etmenler }\end{array}$} & Güvenlik & $\begin{array}{c}\text { Öncel } \\
\text { Kültürler } \\
\text { - Paralel } \\
\text { Kültürlerle } \\
\text { Etkileşim }\end{array}$ & $\begin{array}{c}\text { Yapı } \\
\text { Malzemesi } \\
\text { Üretebilme } \\
\text { Yeteneği }\end{array}$ & $\begin{array}{l}\text { İnançlar ve } \\
\text { Gelenekler }\end{array}$ & $\begin{array}{l}\text { Politikalar } \\
\text { ve } \\
\text { İdeolojiler }\end{array}$ \\
\hline & $\begin{array}{l}\text { Yaşam } \\
\text { Ve Üretim } \\
\text { Biçimleri }\end{array}$ & El Sanatları & $\begin{array}{c}\text { Simge, Prestij } \\
\text { ve Anlam }\end{array}$ & Ekonomik Güç & $\begin{array}{l}\text { Benzeşim } \\
\text { Arayıșları }\end{array}$ \\
\hline \multirow{2}{*}{$\begin{array}{l}\text { Teknolojik } \\
\text { Gelişmelere } \\
\text { Bağlı } \\
\text { Etmenler }\end{array}$} & $\begin{array}{l}\text { Teknolojik } \\
\text { Gösteri } \\
\text { Düșüncesi }\end{array}$ & $\begin{array}{c}\text { Akışkanlara } \\
\text { Direnc }\end{array}$ & $\begin{array}{c}\text { Yapı Üretim } \\
\text { Teknolojileri } \\
\text { ve Endüstriyel }\end{array}$ & & \\
\hline & $\begin{array}{l}\text { Tasarım ve } \\
\text { Sunumda } \\
\text { Sayısal } \\
\text { Yetenekler }\end{array}$ & $\begin{array}{c}\text { Malzemenin } \\
\text { Sınırları }\end{array}$ & & & \\
\hline
\end{tabular}

\section{MATERYAL VE YÖNTEM}

Çalışma materyalini Amsterdam kenti içerisinde Museumplein bölgesinde yer alan Stedelijk Müzesi ek yapısı oluşturmaktadır. Çalışmada, çeşitli ögelerin farklı bağlamlar içerisinde bir araya gelerek benzersiz birleşimler olarak meydana getirdiği biçimlerin üretilmesinde rol oynayan etkenlerden hangilerinin Stedelijk Müzesi ek yapısının biçim oluşumunda rol aldığının tespiti yapılmaktadır. Çalışma kapsamında, Stedelijk Müzesi'nin Amsterdam içinde bulunduğu konum, kent tarihi içindeki yeri, kentsel hayatta kullanımları, ek yapı tasarım sürecinde biçim oluşum etmenleri ve bu etmenlerin gündeme gelme sebepleri değerlendirilmiştir. Çalışmada, araştırma konusu hakkında incelenen ulusal ve uluslararası yayınlar, kitap, dergi, makalelerden elde edilen verilerden, çekilen fotoğraflardan ve niteliksel (katılımcı gözlem ve algısal değerlendirme) sorgulama yöntemine göre alanda yapılan gözlemlerden yararlanılmıştır. Tablo 1'de ortaya konan kriterler bağlamında Stedelijk Müzesi ek yapısı incelenmiş, bu kriterlerin hangilerinin ek yapısı tasarım sürecinde mevcut olduğunu gösteren Tablo 2. oluşturulmuştur.

Amsterdam yaşam koşullarının kalitesi bakımından yapılan sıralamada dünyada 12'nci, Avrupa'da 9'uncu sırada yer alır. Bu sıralama, konut, tüketim malları, ekonomik çevre, sağlık ve tıbbi konular, doğal çevre, okullar ve eğitim, kamu hizmetleri ve ulaşım ve sosyo-kültürel 
çevre gibi bir dizi faktöre dayanır (URL-1). 2018 yılında 13 milyonu aşan turisti kendine çeken Amsterdam'da turizm endüstrisini besleyen ana mekânları müzeler oluşturur (URL-2). Van Gogh Müzesi, Anna Frank'ın Evi, Rijks Müzesi ve Stedelijk Müzesi ziyaretçi sıralaması bakımından şehirde bulunan 437 müzenin önde gelenlerini oluşturur. Şehre gelen turistlerin büyük bir kısmı kültür bölgesi olarak tanımlayabileceğimiz Museumplein'ı ziyaret eder. Museumplein, güney yönünde Rijksmuseum'dan Van Baerlestraat isimli ana caddeye kadar uzanan, kutlamalardan siyasi gösterilere kadar çeşitli etkinlikler için kullanılan geniş açık alandır (Reeves, 2019). Museumplein bölgesinde Rijksmuseum, Van Gogh Müzesi ve Stedelijk Müzesi ana kültür rotasını oluştururken Concertgebouw konser salonu bölge ile ilişki içerisindedir (Mike ve McDonald, 2016). Museumplein'ın çok yakınında bulunan, yeşilliklerin hâkim olduğu bir açık hava düzenlemesi olarak Vondelpark kent sakinlerinin ve turistlerin bir diğer rahatlama alanıdır (Şekil 01).

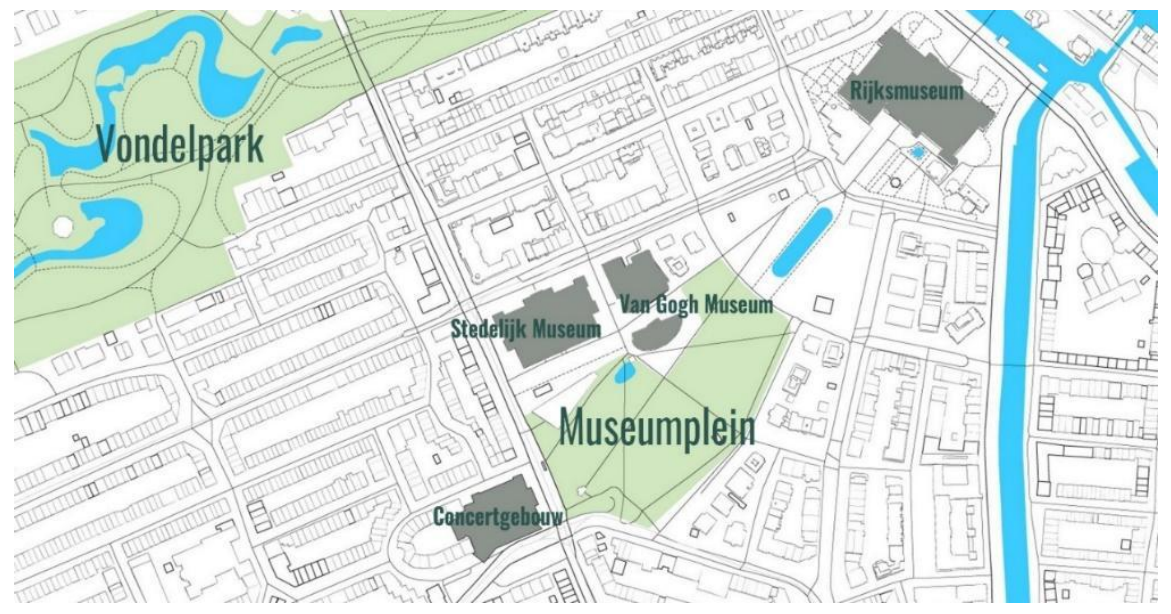

Şekil 01- Amsterdam Museumplein ile Vondelpark ilişkisini gösteren hava fotoğrafı (URL-3).

\section{1 Çalışama Alanı Olarak Amsterdam Stedelijk Müzesi Ek Yapısı}

Stedelijk Müzesi 20.yüzyılın ilk yarısından beri modern ve çağdaş sanat için Amsterdam'ın en önemli ve geniş koleksiyona sahip mekanıdır. 19.yüzyılda, Adriaan Willem Weissman tarafından tasarlanan Stedelijk Müzesi, 1891-1895 yılları arasında bugün Rijksmuseum ve Van Gogh Müzesi'ni de barındıran Museumplein'ın sonunda yer alan Paulus Potterstraat'ta inşa edilmiştir. Cephesi ve kulesi, taş ve kırmızı tuğla kombinasyonu ile tasarlanan yapı, 16. yüzyıl Hollanda'sına hâkim olan Neo-Rönesans tarzdadır (Şekil 02). 


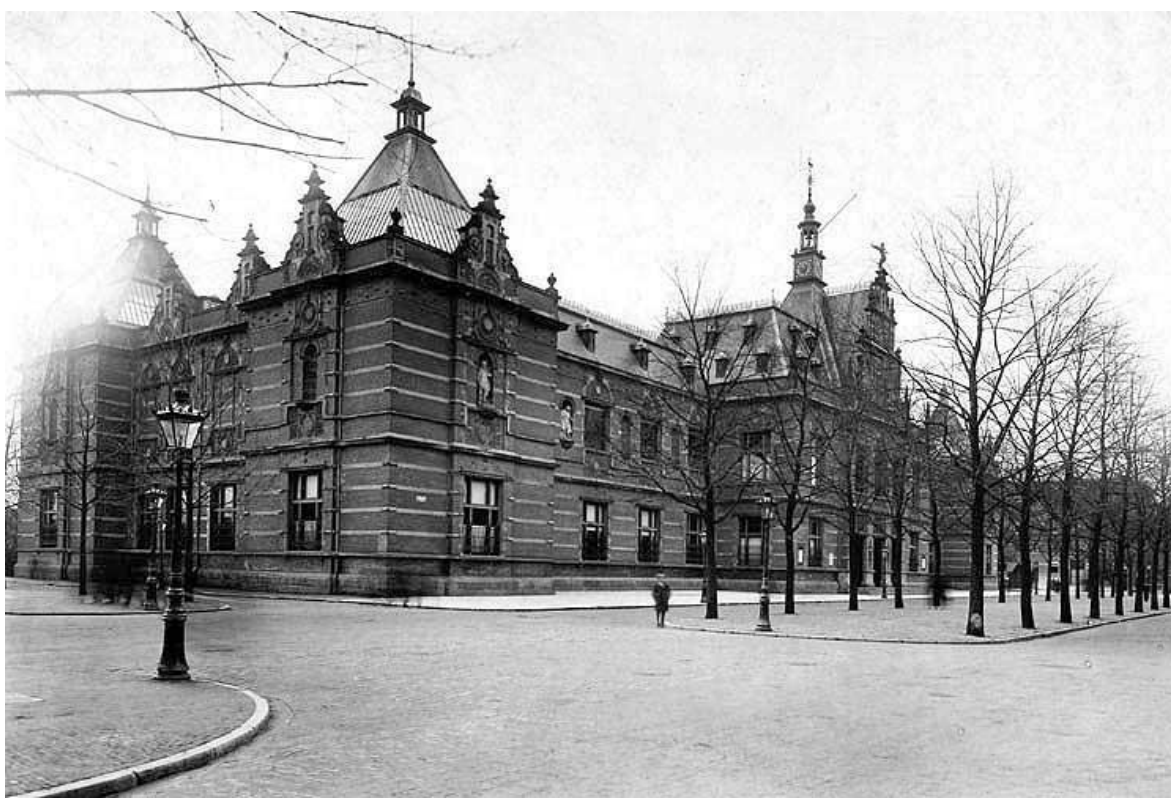

Şekil 02- 19. yüzyılda inşası biten Stedelijk Müzesi fotoğrafı (URL-4).

Ocak 1938'de müzeye küratör olarak atanan Willem Sandberg, müzenin iç duvarları beyaza boyayarak "beyaz küp" olarak tanımlanan sergi alanlarını yaratmıştır (Şekil 03). Sandberg 1945'te müze müdürlüğüne getirilmiştir. Sandberg'in müdahalesi ile Stedelijk, Avrupa modern sanat müzeciliğinde "beyaz küp" kullanılan ilk müze olma ayrıcalığını kazanmıştır. Dünya genelinde ise New York Modern Sanat Müzesi'ni takiben ikinci sırada gelmiştir. O' Doherty (2000), Avrupa müzeciliğinde Stedelijk Müzesi ile ilişkilendirilen beyaz küpü "Beyaz duvarlar, nötr zemin ve süslemesiz mimari içerisinde eserlerin birbirine saygılı biçimde yerleştirildiği, dikkat dağılımını engelleyerek ilginin sanat üzerine yoğunlaşmasını amaçlayan mekânlar" olarak tanımlar. Özellikle modern sanat müzeleri mimarisine hâkim olan beyaz küp, yirminci yüzyılın ikinci yarısından itibaren dünya genelinde tercih edilen sergileme biçimi haline gelmiştir (Giebelhausen, 2005). Beyaz küpün sağladığı faydaların bilincinde olan Sandberg tarafından oluşturulan sade mekânlarda, sergilenecek sanat eserlerinin önüne geçebilecek başka bir şeye yer verilmemesi ile ziyaretçilerinin sanat eserlerine olan ilgisinin dağılmaması sağlanmıştır.

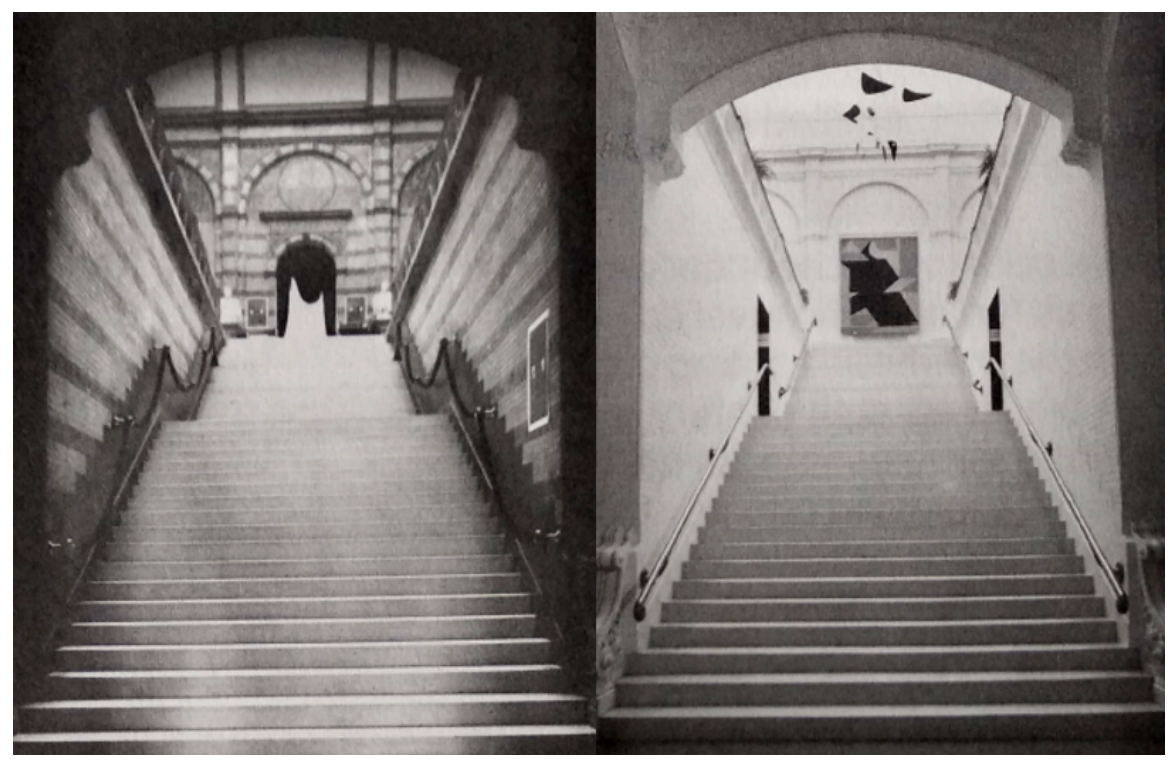

Şekil 03- Müzenin beyaz küp ile özdeşleşen alanlarından birinin, 1938 öncesi ve sonrasını gösteren fotoğraf (Ibelings, 2013). 
1954 yılında deneysel sanatı içermek amacı ile bugün kullanılan yeni ek yapının yerinde "Sandberg Eki" olarak bilinen cam cephelere sahip ek yapı inşa edilmiştir (Şekil 04). Sandberg, 1956'ya kadar bir okuma odası, baskı odası, restoran ve bir oditoryumu mevcut yapının içerisine eklenmesini sağlamıştır.

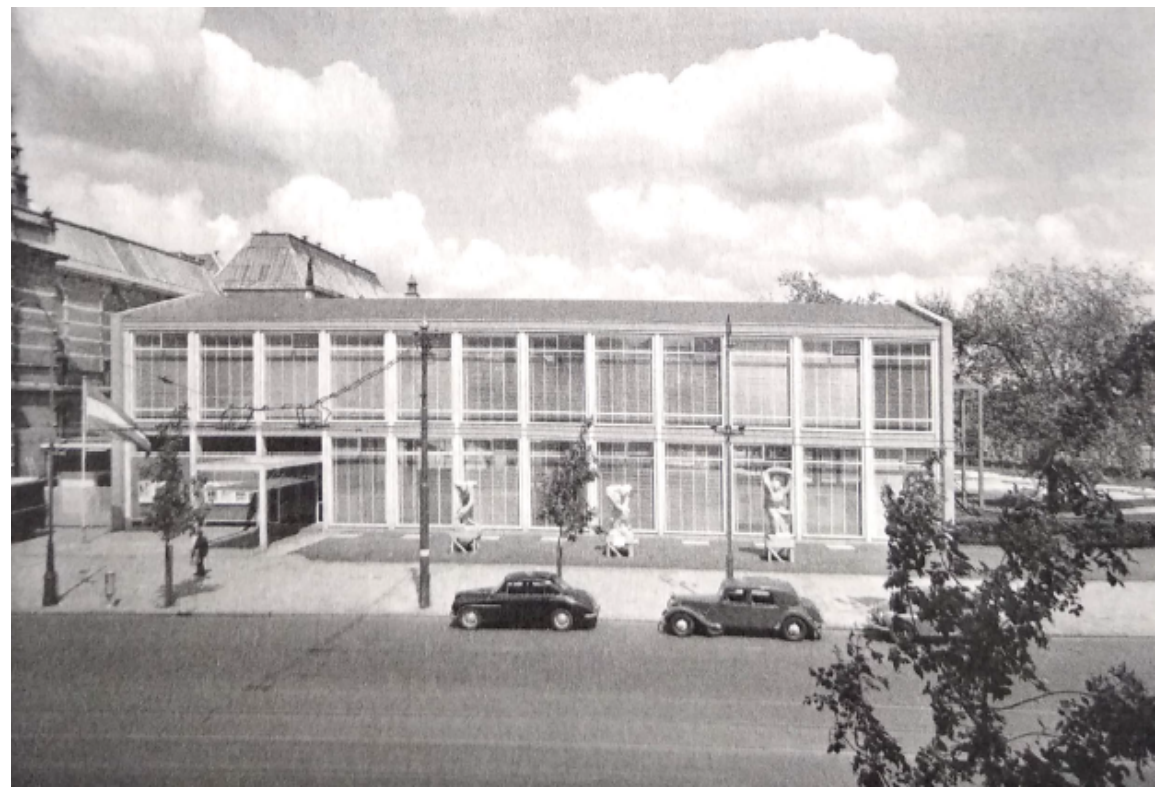

Şekil 04- Sandberg Eki olarak bilinen cam cephelere sahip ek yapının 1971 tarihli durumu (Ibelings, 2013).

Geçen yıllar ile birlikte yetersiz iklim kontrolü başta olmak üzere, binanın modern standartları ve yönetmelikleri karşılayamamasının büyük sorunlara sebep olduğu görülmüştür. Müzenin kuruluşundan beri artan koleksiyonla beraber depo ve sergi gereksinmeleri de büyük ölçüde artmış ve 1993 yılında müzenin çatısından kaynaklanan bir sızıntı sonucunda bazı sanatçıların eserlerinin zarar görmesi ile yapının eksikleri medyanın gündemine gelmiştir. 1990'ların başında yapıyı modernize etmek ve yeni bir ek yapıya sahip olmak için bir yarışma açılmasına karar verilmiştir. Robert Venturi, Wim Quist, Carel Weeber ve Rem Koolhaas gibi mimarların katıımı ile gerçekleştirilen yarışmayı Venturi kazanmıştır. Venturi'nin kazındığı yarışma sonrasında uzun bir süre herhangi bir gelişme yaşanmaması üzerine projelendirme işi 1996 yılında Álvaro Siza'ya verilmiştir (Şekil 05). Yedi yıllık bir sürecin ardından ortaya çıkan tasarımın uygulama maliyetinin beklenenin ötesine geçmesi sebebiyle Siza ile imzalanan anlaşma 2002 yılının sonunda iptal edilmiştir (Ibelings, 2013).

2004 tarihinde, beş Hollandalı mimarlık ofisinin davet edildiği bir yarışma düzenlenmiştir. Davet edilen mimarlık ofislerinin kamu yapıları konusunda uzmanlığını kanıtlamış; restorasyon, tarihi yapılara ek yapı tasarımı ve uygulaması hakkında deneyimli olması gözetilmiştir. İlan edilen sonuçlara göre yarışmayı, müzenin ana girişini var olanın ters yönüne alarak, Museumplein'a doğru çeviren; küvete benzetilen tasarımlarıyla Benthem Crouwel Mimarlık Ofisi kazanmıştır (Şekil 06). 


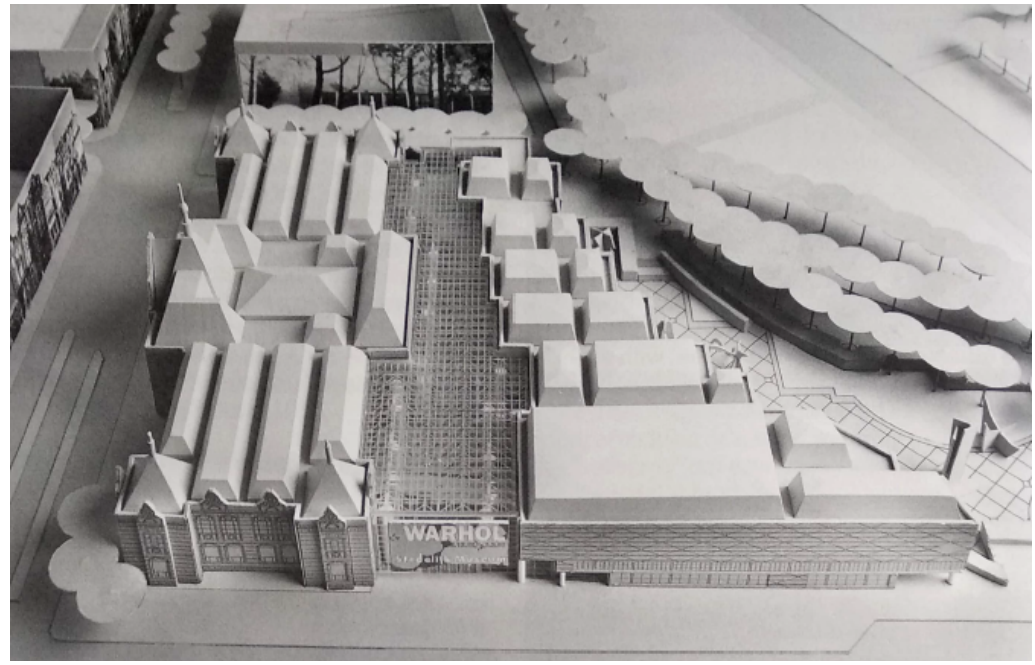

Şekil 05- Venturi tarafından yapılan ek yapı tasarımı (Ibelings, 2013).

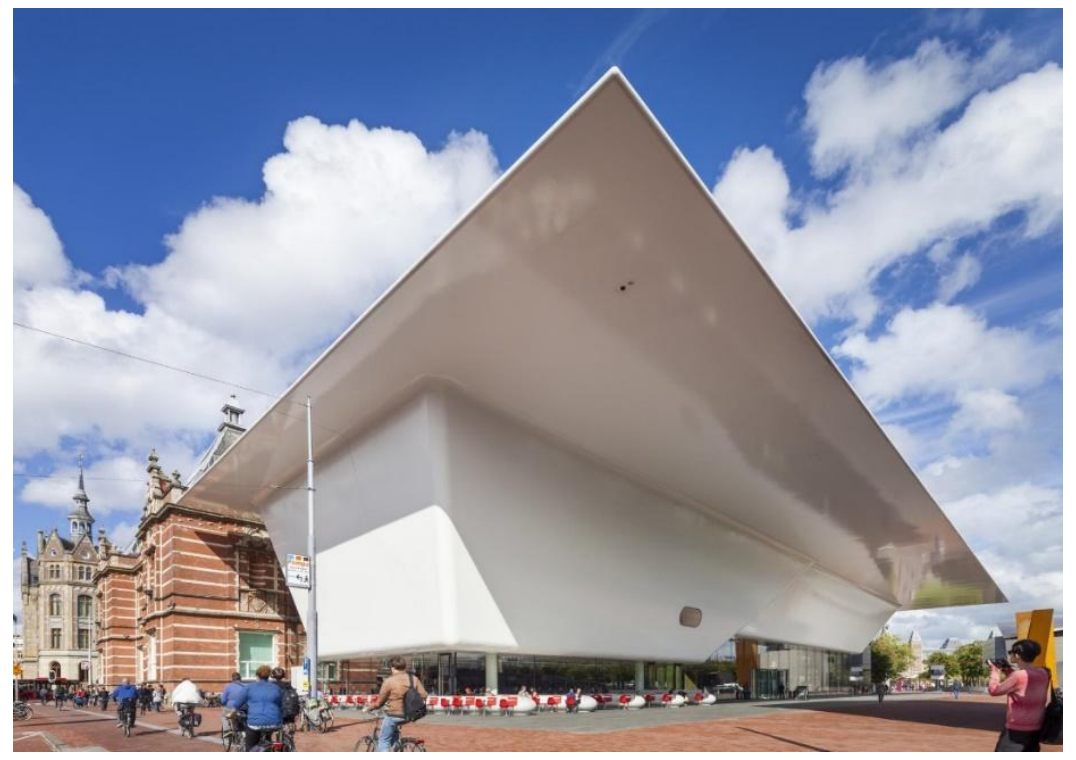

Şekil 06- Stedelijk Müzesi ile sonlanan Amsterdam Museumplein (URL-5).

\subsection{Stedelijk Müzesi Ek Yapısı Biçim Oluşumu}

Ek yapıda sıra dışı bir biçime yönelen Benthem Crouwel'in tasarım faaliyetlerinde rol alan farklı etkenlerden bahsedebilir. Stedelijk Müzesi için açılan yarışmayı kazanan Benthem Crouwel Mimarlık ofisi için yarışmanın sonuç raporunda yapının yönelimi hakkında övgüyle bahsedilmiştir. Museumplein, sahip olduğu doğal ve yapay çevre elemanları ile kamu için bir buluşma noktası ve kentsel hayatın merkezi konumundadır. Museumplein'ın tersi yönünde bulunan Stedelijk Müzesi'nin mevcut ana girişi, Benthem Crouwel'in tasarımı ek yapı ile Museumplein'a doğru yönelmiştir. Bunun sonucu olarak yapının kent hayatına katılımı artırılmıştır (Şekil 07). Jones ve arkadaşlarına (2004) göre kent mekânı ekonomik, politik, sosyal ve kültürel ilişkilerin aracılığıyla somut bir yapıya dönüşür. Bu görüşe temel oluşturan Mumford (1970) ise kenti adeta bir tiyatro sahnesine benzetmiştir. Gehl (2011), sokak yaşamının ve orada hayat bulan faaliyetin çeşitliliği ile kentsel mekânların başarılı sayılabilmesinin mümkün olduğunu söyler. Stedelijk Müzesi, Rijksmuseum'den itibaren başlayan büyük bir açıkığa sahip olan Museumplein'a yüzünü dönmesi ile bölgeyi toplanma alanı olarak kullanan kalabalıklarla ilişki içerisine girerek kentsel mekânda farklı faaliyetlerin birlikteliğine imkân vermiştir. Sahip olduğu uzun saçak ile toplanma anlarında iklimden kaynaklanan olumsuz dış etmenlere karşı koruyucu bir biçimlenmeye sahip olan ek yapı, tamamlanıp hizmete açılamasından önce kentin futbol takımı Ajax'ın şampiyonluk kutlamaları 
sırasında yaşanan olaylar neticesinde zarar görmüş, açılış süreci bir miktar uzamak zorunda kalmıştır.

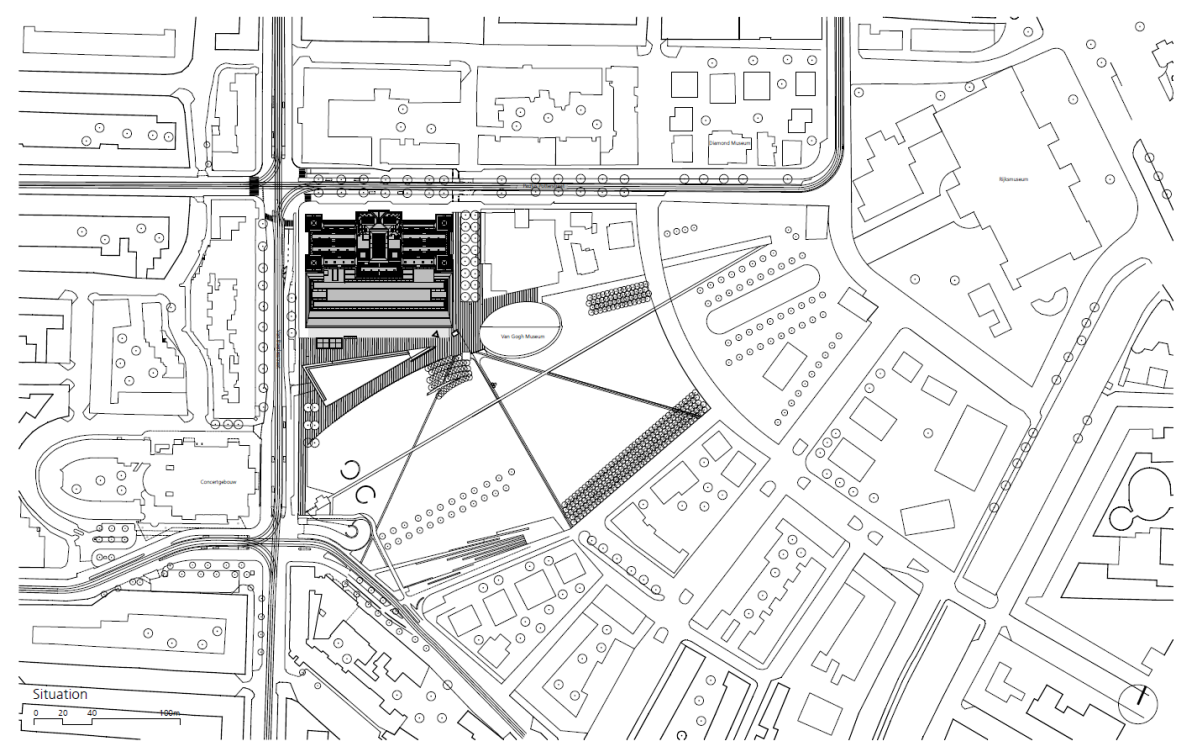

Şekil 07- Museumplein'a yönelen Amsterdam Stedelijk Müzesi (URL-5).

En son Mayıs 2019'da kentin futbol takımı Ajax'ın 34. şampiyonluk kutlamaları için 100.000 kişilik taraftar grubunun topladığı Museumplein bölgesi, kentin coşkulu kutlamalarının ve kitleler için düzenlenen sanat organizasyonlarının yapıldığı bir toplanma alanı olarak Mumford'un benzettiği bir tiyatro sahnesi gibi işlev görür (Şekil 08). Bölge, Kral Willem-Alexander'ın doğum günü kutlamaları sebebiyle her yıl 27 Nisan'da düzenlenen King's Day isimli bayramda yüksek insan yoğunluğunu barındırır.

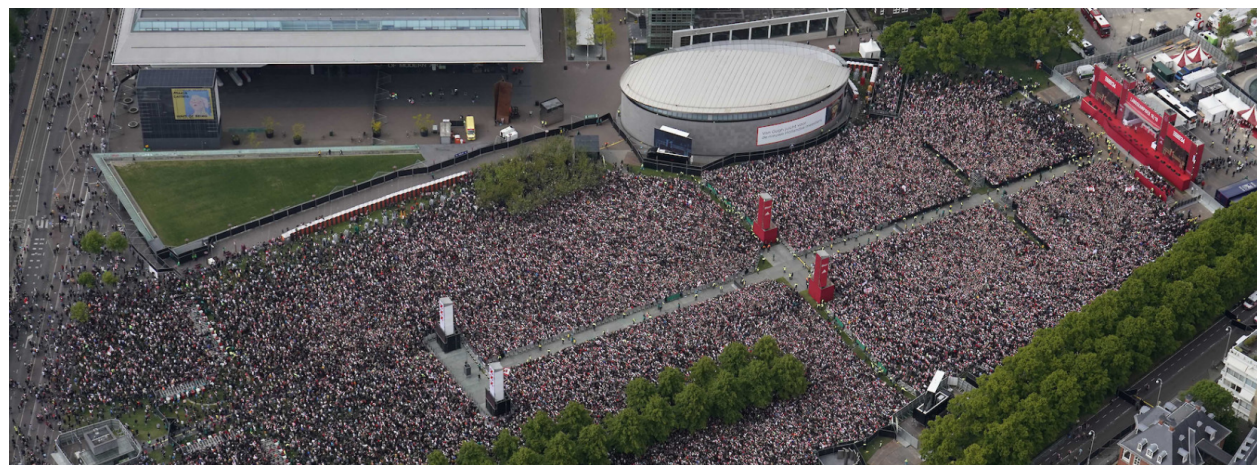

Şekil 08- Ajax isimli futbol takımının 34. şampiyonluk kutlamaları için 100.000 kişilik taraftar grubunun topladığı Museumplein (URL-6).

Gunther Fischer (2015), bir binanın kendi başına anlam kazanamayacağını, çevresinde bulunan yapılarla paylaştığı ilişkiler nedeni ile bir anlama kavuşabileceğini savunur. Güzer (2013), yapıların tekil olarak değil, kentle kurdukları ilişki ve kent belleğindeki anlamları ile değer kazandığına değinir. Kevin Lynch'e (2010) göre kent içinde sembolik anlam taşıyan yapılar, karakteristik özelliklerinin öne çıkarılmasıyla kent sakinleri için cazip hale getirilebilmektedir. Resuloğlu'nun (2020) dediği gibi kentsel mekanların sahip oldukları kimlikler, diğer kent mekanları ile kurdukları ilişkiler ile şekillenir ve okunabilirlik kazanır. Stedelijk Müzesi, Rijksmuseum'dan Concertgebouw'a uzanan bir kültür aksının içerisinde bulunmasının sağladığı ilişkilerle Amsterdam'ın kültür ve sanat hayatında temsil ettiği anlamı kazanır. Müze, 20. yüzyıl başlarında Avrupa Modern Sanat Müzeciliği konusunda sahip olduğu prestijli öncülük konumunu Paris'te Pompidou Kültür Merkezin'in açılışı ile kaybetmiştir. Şahin'e (2011) göre 'ek' sözcüğü "bir şeyin anlamını ya da değerini değiştiren bir biçim birim" 
olarak tanımlanır. Bu tanıma uygun olarak Stedelijk Müzesi ek yapısında Avrupa kültür hayatındaki simgesel anlamına yeniden kavuşmak ve ayrıcalığını vurgulamak amaçlanmıştır. Müze yapısının iç mekanlarına karakteristik kazandıran ve modern sanat içerisinde yer bulan "Beyaz Küp" kavramı, ek yapının kabuk tasarımında çıkış noktası olarak seçilmiştir. İç mekanlara sahip olan temiz ve antiseptik beyaz yüzeylerin içten dışa yansıtılması, ek yapının dikkat çekici, şaşırtıcı ve eskiyle zıtlık yaratan biçim oluşumunda ana karar olarak kullanılmıştır.

Ersen'e (1992) göre çağdaş malzeme kullanımıyla yansıtıcı yüzeylerde geleneksel kent dokusu yansımalarının oluşturulması yöntemi mimari zıtlıklar yaratılabilme imkânı verir. Stedelijk Müzesi'nin ihtiyaçlarını karşılamak amacı ile tasarlanan ek yapısı, Benthem Crouwel'in zıtlıkları kullanan tasarım kararları ile biçimlenmiştir (Yıldız, 2018). Sönmez'e (2017) göre zıtlık, zaman katmanlarının ve sürekliliğin okunabilmesini olanaklı kılmaktadır. Zaman katmanlarının arasındaki ilişki Stedelijk Müzesi ve ek yapısı arasında göze çarpan bir şekilde vurgulanır. Eski yapıyı oluşturan, mat özellikte ki tuğla ve taş malzemeye karşı ek yapıda tercih edilen malzemelerin yansıtıcı özellikleri ile kent yaşamının dış kabukta yansımaları oluşur. Ek yapı tasarımı ile yaratılan zıtıı̆ın amacı, ziyaretçiler dışında bölgede bulunan kişilerin de dikkatlerini çekerek merak uyandırmak, şaşırtmak ve onları yapıya davet etmektir. Öztürk'ün (2017) belirttiği gibi Stedelijk Müzesi’nde eski yapı ile ek yapı arasında ortaya konan zıtlık dışardan bakan gözlemciler için çok belirgindir. Buna karşın ziyaretçilerin eski ve yeni sergi mekanları arasında geçişlerinde bu zıtlıkları fark etmeleri mümkün değildir.

Benthem Crouwel Mimarlık ofisi daha önce üretilmemiş boyutta kesintisiz kompozit yüzeyi, küvet biçimini vermek için tasarımlarında kullanmaya karar vermişti. Tarihi yapının sahip olduğu beyaz sergi salonlarının prestijli imgesini ek yapının biçim oluşumunda kullanmak üzere modern teknolojinin olanaklarından faydalanılmıştır. İç mekânda oluşturulan iki köprüyü kullanarak tarihi yapıya bağlantı sağlayan ek yapının kabuk tasarımında iklim önemli bir girdi olmuştur (Şekil 09).

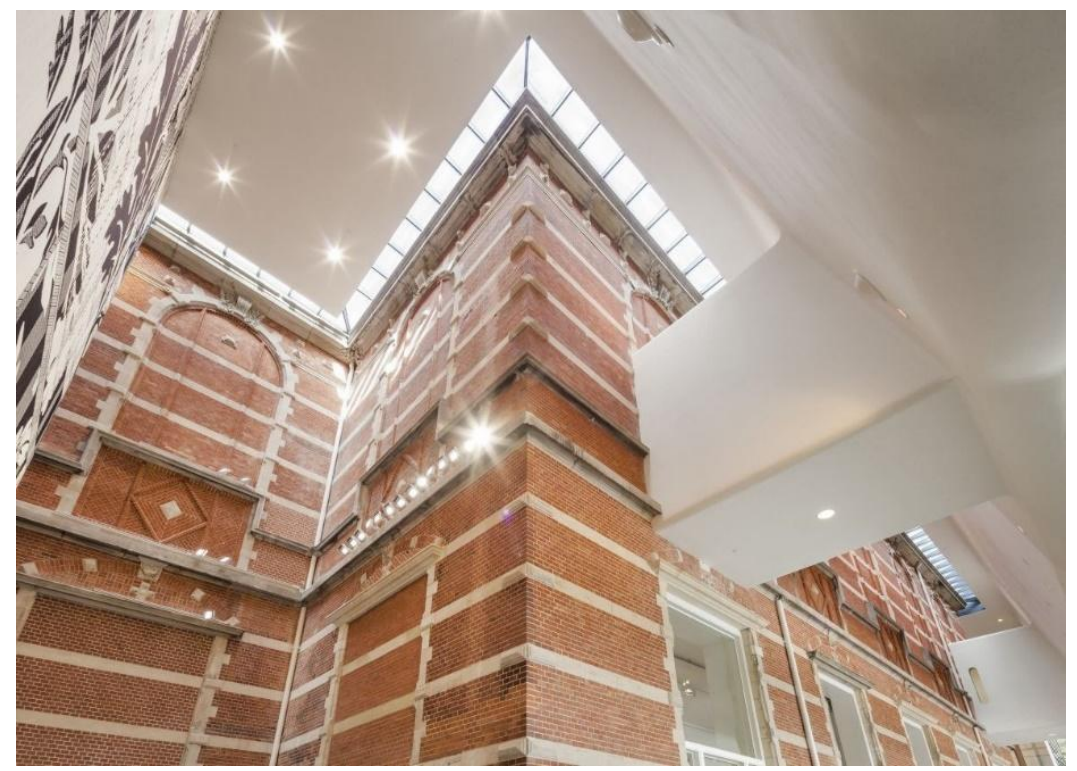

Şekil 09- Tarihi bina ile ek yapı arasında üst kat ilişkisini sağlayan köprüler (URL-5).

Amsterdam, yıl içerisinde gözlemlenen -25 ile +35 arasında sıcaklık değerleri ile malzemelerin sınırlarını zorlayan bir iklime sahiptir. 8500 kilometre uzunluğundan fazla karbon ve aramid elyaf kombinasyonu kullanılarak üretilen fiber malzeme ile dış kabuk oluşturulmuştur. Kesintisiz ve ek yeri olmayan kompozit yüzeyler üretilmesine imkân veren fiber malzemenin kullanılması ile yapı kabuğunun, yıl içerisindeki sıcaklık farklarından etkilenmesi en az düzeye indirilebilmiştir (Şekil 10, Şekil 11). 


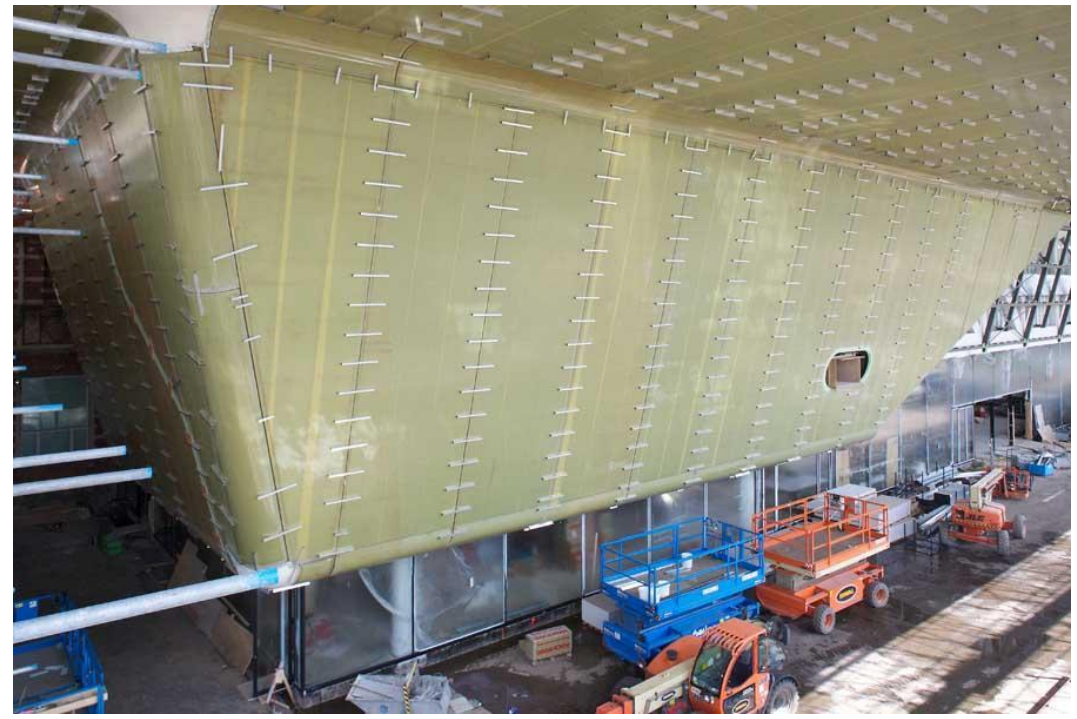

Şekil 10- Karbon ve aramid elyaf kombinasyonu kullanılarak üretilen fiber malzeme ile üretilen yüzeyler (URL-8).

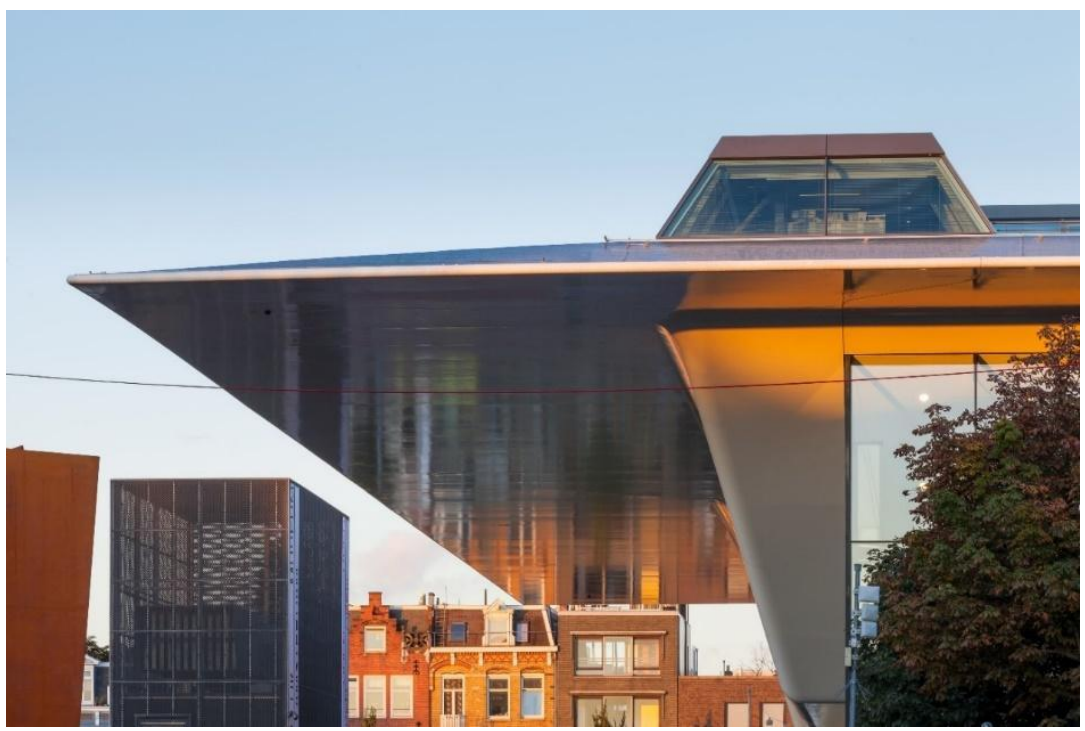

Şekil 11- Sıcaklık farkında en iyi ısıl genleşme performansını verecek, kesintisiz ve ek yeri olmayan yüzeyler oluşturulmuştur (URL-5).

Statik bakımından çelikten beş kat güçlü ve çok daha hafif olan, ateş ve darbeye dayanıklı fiber malzeme sayesinde kabuk bütününde etkili olan, diş minesi parlaklığında, kir tutmayarak sürekli temiz kalan görünüme ulaşılmıştır (URL-7).

Ek yapıdan Museumplein'a uzanan büyük saçağın biçimlenişinde estetik kaygılar değil işlevsellik ön planda tutulmuştur. Yapının konumlanışı ve iklim verileri sebebi ile yılın sıcak zamanlarında güney cephesindeki saydam yüzeylerin sebep olabileceği sıcaklık artışlarının engellenmesi bu sıra dışı biçimlenişin oluşumunda önemli etkendir. Ek yapının küvet biçimini tanımlayan saçak, kış ve ilkbahar dönenlerinde avludaki ziyaretçilerin dış hava koşullarına karşı korunabilecekleri işlevsel bir öge görevi üstlenir. Eskiden ana binada bulunan oditoryum, ek binada saçağın arkasına alınarak ana yapıda sergi alanlarının oranı arttırılmışır. Saçağın koruduğu kamusal açık alanın altında yer alan bodrum katı boyunca Avrupa'nın en büyük açıklıklı sergi salonu inşa edilmiştir (Şekil 12). 


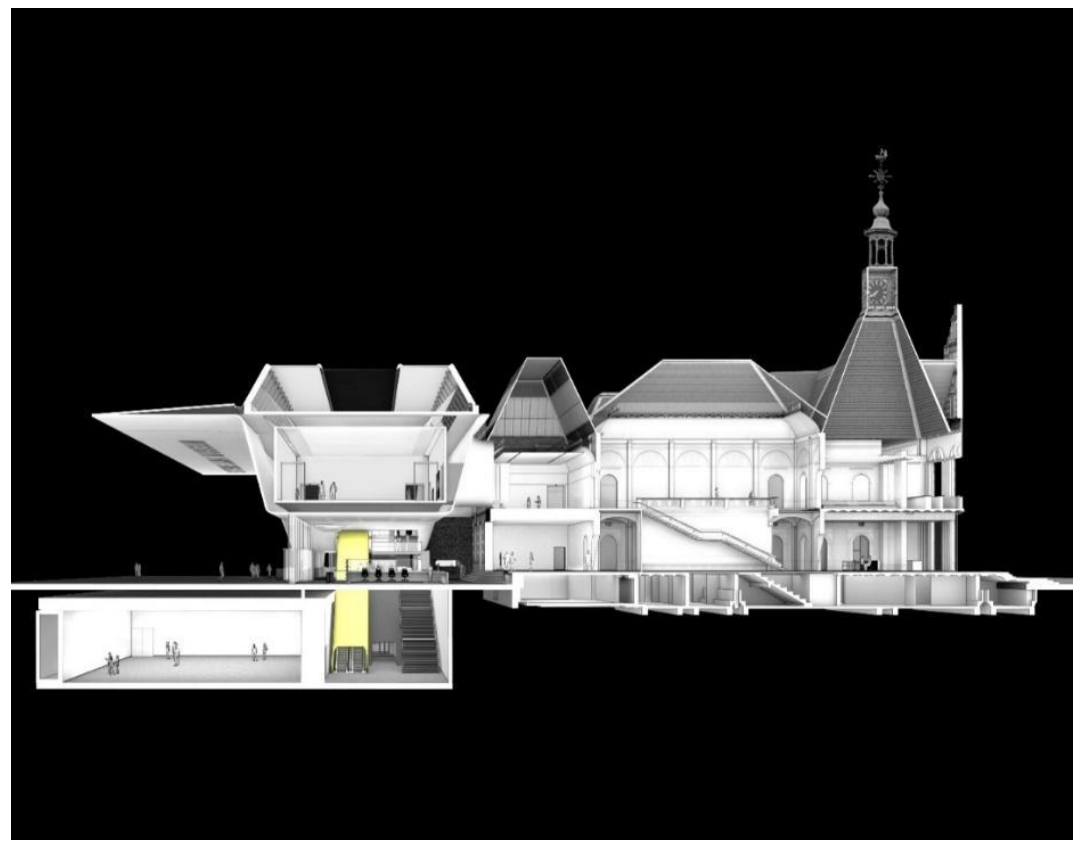

Şekil 12- Müzenin Museumplein'a doğru uzanan, toprak altındaki Avrupa'nın en büyük açıklığına sahip sergi alanını gösteren kesit (URL-5).

Zorlu dış hava şartlarından etkilenemeyecek, temizlik, bakım ve tamir masrafları gerektirmeyecek; öngörülenden 20 milyon Euro fazla maliyet getiren kabuğun tercihi ile kentin ve Hollanda'nın sanat tarihindeki yeri ile birlikte ekonomik gücü de gözler önüne serilmek istenmiştir. Amsterdam'ın modern sanat müzeciliğinde Avrupa'daki öncü konumuna vurgu yapması için ek yapının tasarım sürecinde sayısal yeteneklerden, inşa sürecinde ise endüstriyel üretim teknolojilerinden faydalanılmıştır. Kentin ve kentlinin yaşam biçimlerinde etkisini gösteren ekonomi ve kültürel birikimin simgesi olarak biçimlenen Stedelijk Müzesi, turistler ve kent sakinleri için ilgi çekici bir çevre ögesi olarak görev üstlenir (Şekil 13). Van Eyck, Vermeer, Rrembrandt gibi büyük Hollandalı sanatçılarının eserlerinin sergilendiği Rijksmuseum ve Van Gogh'un eserlerinin sergilendiği Van Gogh Museum ile sanat tarihindeki yerini vurgulayan Amsterdam için Stedelijk Müzesi, sahip olduğu eserler ve sıra dışı mimarisi ile güncel sanat dünyasında ülkenin gurur kaynağı olmuştur. 


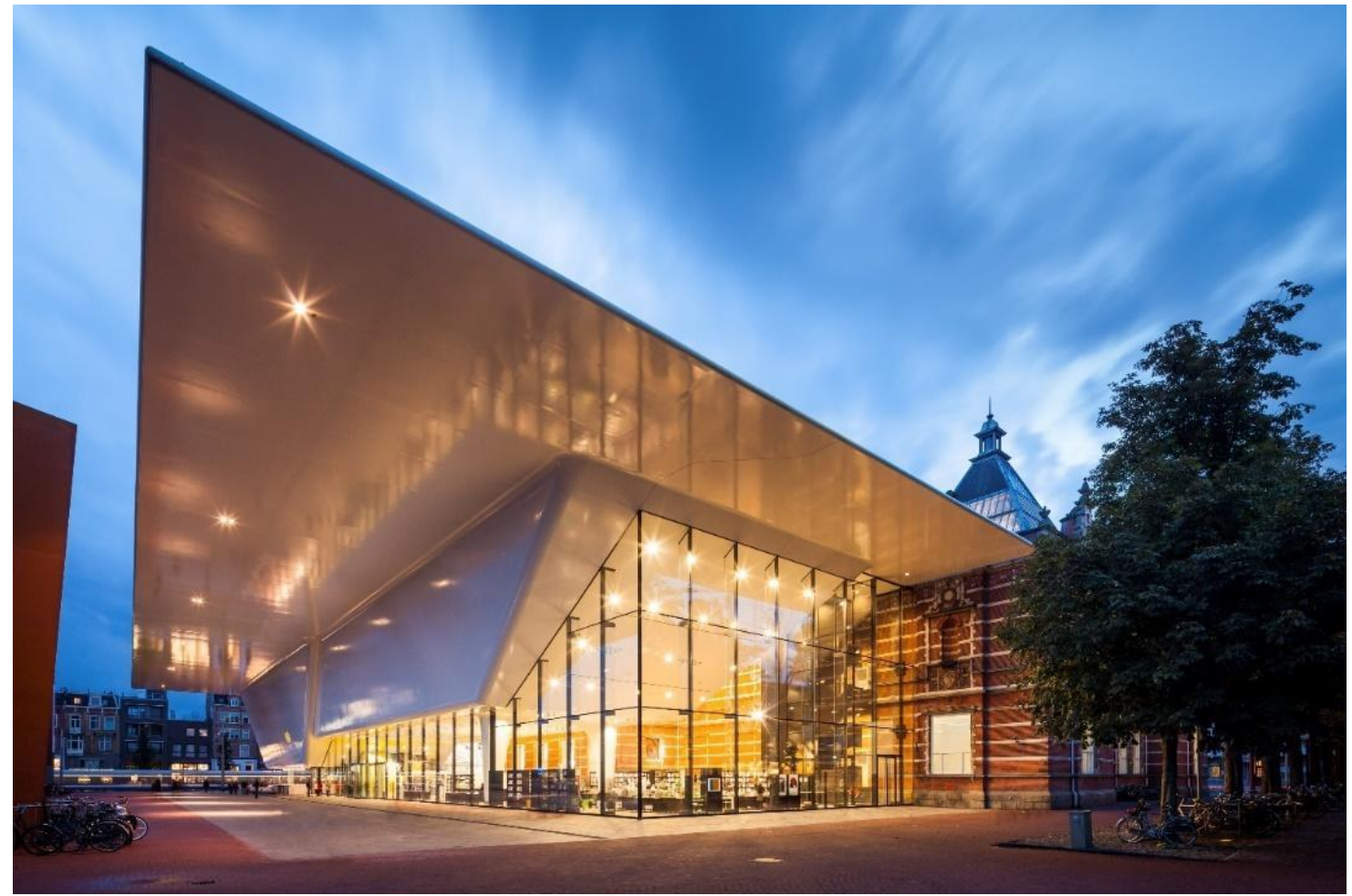

Şekil 13- Stedelijk Müzesi turistler ve kent sakinleri için günün farklı saatlerinde ilgi çekici bir çevre ögesi olarak görev üstlenir (URL-5).

\section{BULGULAR}

Çalışma kapsamında Stedelijk Müzesi ek yapısı çalışma alanı olarak belirlenmiştir. Biçimlenmeye etki eden faktörlerden hangilerinin farklı bağlamlar ile bir araya gelerek Stedelijk Müzesi ek yapısı örneğinde etkili olduğunun tespitini yapılmaktadır. Stedelijk Müzesi ek yapısı, Tablo 1 üzerinde gösterilen mimari yapıların biçimlenişine etki eden faktörlerden bazılarının farklı bağlamlarda kesişmesini içermektedir. Bu faktörler arasındaki mevcudiyetler Tablo 2 içerisinde gösterilmiştir. 
Tablo 2. Biçime etki eden faktörlerin Stedelijk Müzesi ek yapı tasarımında mevcudiyetlerini gösteren gruplama.

\begin{tabular}{|c|c|c|c|c|c|}
\hline \multirow{2}{*}{$\begin{array}{l}\text { Çevresel } \\
\text { Etmenler }\end{array}$} & İklim & $\begin{array}{c}\text { Çevreden } \\
\text { Sağlanabilen } \\
\text { Doğal Yapi } \\
\text { Malzemeleri }\end{array}$ & $\begin{array}{l}\text { Zemin Özelliği } \\
\text { ve Deprem } \\
\text { Faktörü }\end{array}$ & & \\
\hline & Topoğrafya & Yapay Çevre & $\begin{array}{c}\text { Manzara ve } \\
\text { Uygun } \\
\text { Yönelme }\end{array}$ & & \\
\hline \multirow{2}{*}{$\begin{array}{l}\text { Tasarımcının } \\
\text { Sahip Olduğu } \\
\text { Değer ve } \\
\text { Düşünce } \\
\text { Düzeyine } \\
\text { Bağlı } \\
\text { Etmenler }\end{array}$} & Akımlar & $\begin{array}{l}\text { Çevresel } \\
\text { Odaklı } \\
\text { Tasarım } \\
\text { Düşüncesi }\end{array}$ & $\begin{array}{c}\text { Dikkat } \\
\text { Çekmek, } \\
\text { Şaşırtmak }\end{array}$ & & \\
\hline & $\begin{array}{l}\text { Biçim ve Yer } \\
\text { Deăiștirebilme } \\
\text { Yeteneği } \\
\text { Arayışları }\end{array}$ & İşlevsellik & $\begin{array}{c}\text { Tasarım } \\
\text { Yaklaşımları }\end{array}$ & & \\
\hline \multirow{2}{*}{$\begin{array}{l}\text { Toplumsal } \\
\text { Kabul ve } \\
\text { Yerleşik } \\
\text { Değerler } \\
\text { Sistemine } \\
\text { Bağlı } \\
\text { Etmenler }\end{array}$} & Güvenlik & $\begin{array}{c}\text { Öncel } \\
\text { Kültürler } \\
\text { - Paralel } \\
\text { Kültürlerle } \\
\text { Etkileşim }\end{array}$ & $\begin{array}{c}\text { Yapı } \\
\text { Malzemesi } \\
\text { Uretebilme } \\
\text { Yeteneği }\end{array}$ & $\begin{array}{l}\text { Inançlar ve } \\
\text { Gelenekler }\end{array}$ & $\begin{array}{l}\text { Politikalar } \\
\text { ve } \\
\text { Ideolojiler }\end{array}$ \\
\hline & $\begin{array}{l}\text { Yaşam } \\
\text { Ve Ûretim } \\
\text { Biçimleri }\end{array}$ & El Sanatları & $\begin{array}{l}\text { Simge, Prestij } \\
\text { ve Anlam }\end{array}$ & Ekonomik Güç & $\begin{array}{l}\text { Benzeşim } \\
\text { Arayışları }\end{array}$ \\
\hline \multirow{2}{*}{$\begin{array}{l}\text { Teknolojik } \\
\text { Gelişmelere } \\
\text { Baq̆lı } \\
\text { Etmenler }\end{array}$} & $\begin{array}{l}\text { Teknolojik } \\
\text { Gösteri } \\
\text { Düşüncesi }\end{array}$ & $\begin{array}{c}\text { Akışkanlara } \\
\text { Direnç }\end{array}$ & $\begin{array}{l}\text { Yapı Üretim } \\
\text { Teknolojileri } \\
\text { ve Endüstriyel }\end{array}$ & & \\
\hline & $\begin{array}{l}\text { Tasarım ve } \\
\text { Sunumda } \\
\text { Sayısal } \\
\text { Yetenekler }\end{array}$ & $\begin{array}{l}\text { Malzemenin } \\
\text { Sınırları }\end{array}$ & & & \\
\hline
\end{tabular}

Stedelijk Müzesi ek yapısı için çalışma kapsamında yapılan tespitlere göre yapının biçimlenişe etki eden faktörler şunladır:

Çevresel etmenler bakımından biçimlenişe etki eden faktörler:

- İklim

- Yapay çevre

- Manzara ve uygun yönelme

Stedelijk Müzesi ek yapısında iklimin zorlayıcı şartlarına karşı gelebilecek seçilen fiber malzeme oluşturulan kabuğun kaplanmasında kullanılmıştır. Diş minesi renginde ki yüzeylerde kent yaşamının yansımaları oluşturularak çevrenin kültürel kimliği dışardan algılanır. Yapının geleneksel girişi Museumplein bölgesine taşınmış ve güney yönünde bulunan bu girişi iklim şartlarına karşı koruyacak bir saçak tasarlanmıştır.

Tasarımcının sahip olduğu değer ve düşünce düzeyine bağlı olarak biçimlenişe etki eden faktörler:

- Akımlar

- Çevresel odaklı tasarım düşüncesi

- İşlevsellik

- Dikkat çekmek, şaşırtmak

- Tasarım yaklaşımları 
Stedelijk Müzesi ek yapısı tasarımında sıra dışı biçimlenmenin arkasında tasarımcıların aldığı pek çok karar yer almaktadır. Günümüz dijital tasarım ve endüstriyel üretim şekillerinin hakim olduğu mimarlık camiasında yapılan tasarımda, iklim şartlarına karşı koruyucu bir işlevsellik ön plandadır. Kabuğun oluşumunda kir tutmayan malzemeler ile sürekli temiz kalan yüzeylerin oluşturulması ile bina bakım maliyetlerini düşürülmesi, kaynak kullanımlarının sınırlandırılması ve yapı ömrünün uzatılması hedeflenmiştir. Küveti hatırlatan biçimlenmesiyle Stedelijk Müzesi ek yapısı, bölgeden geçen insaların dikkatini çekerek onları müzenin ziyaretçisi olmaya davet etmektedir.

Toplumsal kabul ve yerleşik değerler sistemine bağlı olarak biçimlenişe etki eden etmenler:

- Yaşam ve üretim biçimleri

- Simge, prestij ve anlam

- Ekonomik güç

Stedelijk Müzesi, 20.yüzyılın ilk yarısından beri modern ve çağdaş sanat için Amsterdam'ın en önemli ve geniş koleksiyona sahip mekânıdır. Avrupa içinde beyaz küp sergi alanlarına sahip ilk modern sanat müzesi olması sebebi ile Stedelijk Müzesi, Avrupa müzecilik tarihinde Amsterdam'ı ayrıcalıklı konuma koyar. Kent, Centre Pompidou'nun açılışından itibaren Avrupa modern sanat müzeciliğinde sahip olduğu önemini kaybetmiştir. Kentin yönetimi, Stedelijk Müzesi ek yapısı ile kentli yaşamının sanatla iç içe olma durumunu ve Museumplein'da kurgulanan sanat bölgesinin prestijinin arttırılmasını istemiştir. Oluşturulan sıra dışı biçimlenmede yapının "beyaz küp" sergi alanları ile kazandığı anlam vurgulanmış ve bu biçimlenmenin üretimi için kentin ekonomik kaynaklarını zorlayacak malzemeler seçilmiştir. Ek yapı için ortaya çıkan maliyetler yüksek olsa bile yapının tamamlanması ve hedeflenen amaçlara ulaşabilmek uğruna kent sakinlerinin desteği sağlanmıştır.

Teknolojik gelişmelere bağlı olarak gelişen biçimlenişe etki eden faktörler:

- Teknolojik gösteri düşüncesi

- Tasarım ve sunumda sayısal yetenekler

- Malzemenin sınırları

- Yapı üretim teknolojileri ve endüstriyel yetenekler

Günümüzde çevresel ve kültürel değişimlere ek olarak yapı teknolojilerinin gelişimi hızlanmış ve yapı malzemeleri çeşitlenmiştir. Gelişen teknolojinin sunduğu yeni malzeme olanakları tasarım sürecini etkilemekte ve yön vermektedir. Stedelijk Müzesi ek yapısı tasarım sürecinde, daha önce mimari yapılarda kullanımına rastlanılmayan, yat imalat teknolojilerinde faydalanılan fiber malzemelere başvurulmuştur. Stedelijk Müzesi ek yapısı ile kentin denizcilik konusunda sahip olduğu teknoloji, bilgi ve üretim birikimi farklı sektörlerde kullanım imkân bulmuş ve kentin endüstriyel kimliğini mimari üretimlerde de sergilemesine imkânı oluşmuştur.

\section{DEĞERLENDİRME VE SONUÇ}

Mimarlık dünyası içinde biçim, bir yapıyı oluşturan mekanların ve kabuğun hatlarını ifade eden bir kavram olarak algılanan şekil, renk ve dokudan fazlasını, tüm unsurların organik birlikteliğini ve uyumunu ifade eder. Rapoport'a (1969) göre, inşa etmek kültürel bir olgu olduğundan, inşaat organizasyonu ve oluşturulan biçimler iklim koşulları ve topografik yapı gibi çeşitli çevresel şartlar haricinde ait olduğu kültürel ortamdan etkilenir. Biçimin oluşumu hakkında ki çeşitli görüşlere göre bu süreci etkileyen çeşitli etmenler bulunmaktadır. Bunlar temelde mimari yapının yer aldığı bölgeden kaynaklanan fiziksel çevreye etkileri ile sosyal çevre etkileri olarak karşımıza çıkmaktadır.

Biçimlerin oluşma etkenlerini özelleştirmek gerekirse, dört ana başlık altında toplamak mümkündür. Çevresel etmenler iklim, topoğrafya, manzara, malzeme, yapay çevre ve deprem faktörü gibi çeşitli alt başlıklara ayrılabilmektedir. Diğer üç etmen ise temelde sosyal çevre etmenleri olarak adlandırılabilir. Bunlar, tasarımcı kimliğinde görev alan mimarın sahip olduğu düşünce sisteminden kaynaklanan etkiler, içinde yaşanılan topluma ait değerler sisteminden kaynaklanan etkiler ve kaçınılmaz olarak gerçekleşen teknolojik gelişmelerden kaynaklanan etkiler olarak özetlenebilirken bunlarda her biri çeşitli alt başlıklara ayrilabilmektedir.

Mimari bir yapının biçimini oluşturan kavramlar, birbirlerinden bağımsız ve kopuk olarak yapıya etki etmeyip birbirleri ile ilişkili içerisine girerek tasarım sürecine dahil olurlar. Stedelijk Müzesi ek yapısının biçim oluşumunda, fiziksel ve sosyal çevre etmenleri birlikte rol alırken iki zaman dilimini arasındaki farkı ortaya koyan bir yaklaşım merkeze alınmıştır. 
Güncel tasarım düşüncelerinin ve üretim teknolojilerinin hakim olduğu ek yapı ile eski yapının şimdiki zamanda birlikteliğini oluşturan biçimlenişin ardında pek çok etmen birbirleriyle ilişkilidir. Sıra dışı biçimlenişin sebebi ile halk arasında "küvet" olarak adlandırılan Stedelijk Müzesi ek yapısında varlığı tespit edilen etmenlerin kendi aralarında kurduğu ilişkiler, biçim oluşumunda farklı kararların değişik düzeylerde rol oynadığını ortaya koyar. Bu ilişkiler kurgulanırken yapıya yüklenen prestij ve anlam ilk sırada yer alırken, ardından dikkat çekmek, işlevsellik ve endüstriyel yetenekler gibi etmenler öncelikli roller üstlenmiştir. Yapıların biçimsel oluşum sürecinde rol alan etkenler arasında eşit düzeyde önem ve öncelik sıralamasının olmadığı, bazılarının tasarım sürecinde daha ön planda tutularak diğerlerine öncülük ettiği Stedelijk Müzesi ek yapısı örneği ile ortaya konulmuştur.

\section{KAYNAKLAR:}

Akalın, I. ve Halık, Ş. 2011. Türkçe Sözlük, 11. Baskı, T.C. Atatürk Kültür, Ankara: Dil ve Tarih Yüksek Kurumu Türk Dil Kurumu Yayınları

Alexander, C. 1964. Notes on the Synthesis of Form, First Edition, Cambridge: Harvard University Press

Bacon, E. N. 1974. Design of Cities, Revised Edition, New York: Penguin Books

Botton, A.D., (2007). Mutluluğun Mimarisi, (çev.) Banu Tellioğlu Altuğ, İstanbul: Sel Yayıncilık

Broadbent, G. 1973. Design in Architecture, London: John Wiley \& Sons

Ching, F., D., K. 2016. Mimarlık, Biçim, Mekân, Düzen (Architecture: Form, Space, \& Order) (çev.) Sevgi Lökçe, İstanbul: Yapı Endüstri Merkezi Yayınları

Crisman, P. 2007. Form, Style and Materials Sections of the Whole Building Design Guide. Virginia: National Institute of Building Sciences.

Dağgülü, İ. ve Dağgülü, M. 2019. Mimarlıkta Biçimlerin oluşma Etkenleri, Yayınlamamış ders notları, İstanbul. YTÜ

Demirkaya D. 2003. Mimarlıkta Kare ve Devinimi, Yüksek Lisans Tezi, K.T.Ü. Fen Bilimleri Enstitüsü, Trabzon

Düzgün. H. 2016. Bina İşlevi ile Bina Biçimi İlişkisinde Çizge Teorisi Kullanımı İle Veri Eldesi. Doktora Tezi. Yıldız Teknik Üniversitesi Fen Bilimleri Enstitüsü Mimarlık Anabilim Dalı Mimari Tasarım Programı, İstanbul.

Elaver, R. (2012). Form, Functıon, Emotıon: Desıgning For The Human Experience ,International Conference On Engineering And Product Desıgn Education 6 \& 7 September 2012, Artesis University College, Antwerp, pp.267-214, (In English).

Ersal L. Ö. 2013. Mimari Mekânın Biçimlendirilmesi ve Anlam Boyutu: Ontolojik Yaklaşım, Yüksek Lisans Tezi, İTÜ Mimarlık Anabilim Dalı Mimari Tasarım Programı

Ersen, A. (1992). Yeniden İşlevlendirilen Tarihi Yapılar, Modern Ekler ve Çağdaş Tasarım, Arredamento-Dekorasyon, S.5, s.102-105

Etike B. A. ve Dağgülü M. 2019. Bina Biçimlenmesinde Deneyim Anı Faktörü: Berlin Yahudi Müzesi Örneği, Ankara: Gece Akademi

Fischer, G., 2015, Mimarlık ve Dil (Architektur und Sprache) (çev.) Fatma Erkman Akerson, İstanbul: Diamon Yayınları

Gehl, J. 2011, Life Between Buildings- Using Public Space, London: Island Press

Giaccardi, E. ve Fischer, G. 2008, Creativity and Evolution: a Metadesign Perspective, Digital Creativity, 19(1), 19-32.

Giebelhausen, M., 2005, "The Architecture is The Museum", New Museum Theory And Practise, (ed.) Janet Marstine, Blackwells Publishing, Singapore

Güzer, A. (2013). Mimarlıkta Modern Mirasın Korunması: TEDÜ/Türk Eğitim Derneği Üniversitesi, Mimarlık, S.371, s.21-25

Hasol, D. 2014. Ansiklopedik Mimarlık Sözlüğü, İstanbul: YEM Yayınları 
Jones, M., Jones, R. and Woods, M. 2004, An Introduction to Political Geography: Space, Place and Politics, London: Routledge

Ibelings, H. 2013, Stedelijk Architecture, Amsterdam: nai010 Publishers

İzgi, U. 1999. Mimarlıkta Süreç, Kavramlar, İlişkiler, İstanbul: YEM Yayınları

Kıran, A. ve Polatoğlu, Ç. 2011. Bina Bilgisi’ne Giriş, Dördüncü Basım, İstanbul: YTÜ Basım Yayın Merkezi

Lynch, K. 2010, Kent İmgesi (The Image of the City), (çev.) İrem Başaran, İstanbul: Türkiye İş Bankası Kültür Yayınları

Mike, G. ve McDonald, G. 2016. Insight Guides Explore Amsterdam-Insight Guides, UK: APA Publications

Milliyet Gazetecilik. 1986. Büyük Larousse Sözlük ve Ansiklopedisi, Cilt No: 22, İstanbul.

Mitchell, W. 1990. The Logic of Architecture, Design, Computation and Cognition, Second Edition, Cambridge: MIT Press

Moussavi F. 2011. Biçimin İşlevi (The Function of Form), (çev.) Pelin Derviş, İstanbul: YEM Yayın

Mumford, L. 1970, The Culture of Cities, Toronto: Harvest Books

O'Doherty B. 2000. Inside the White Cube: The Ideology of the Gallery Space, San Francisco: The Lapis Press

Onat, E., 2010. Mimarlık, Form ve Geometri, Efil Yayınevi

Öztürk, S. D. (2017) Tasallut Teamüle Karşı: Amsterdam Stedelijk Müzesi, Yapı Dergisi, $\mathrm{S} .432$

Rapoport, A., 1969. House Form and Culture. USA: Prentice Hall

Reeves, J. 2019. The Rough Guide to Amsterdam, UK: APA Publications

Resuloğlu, Ç. (2020). Yapı, Anlam ve Kimlik üzerinden Ankara, Tunalı Hilmi Caddesi'ni Yeniden Anlamak, Journal of Art and Design, Volume 8, s226-234

Shahn, B. 1957. The Shape of Content, Cambridge: Harvard University Press

Sönmez, A. (2017). Tarihi Yapı ve Ek Yapı İlişkisinde Çağdaş Yaklaşımlar Alman Tarih Müzesi ve Çağdaş Ek Yapısı, Yapı Dergisi, S.432

Şahin, M. (2011). Bir Yanılsama: Ek, Mimarlık, S.359, s.33-39

URL-1,

AMS in numbers

2018-2019, https://www.iamsterdam.com/en/business/why-amsterdam/ams-in-numbers, (accessed in: 05.01.2021), (In English).

URL-2 Key Figures 2019- Amsterdam as meeting destination, https://www.iamsterdam.com/media/pdf/corporate/kerncijfers_brochure_20182019 _hr.pdf, (accessed in: 22.11.2020), (In English).

URL-3 https://snazzymaps.com, (accessed in: 06.01.2021), (In English).

URL-4 Posters from the Stedelijk Museum Amsterdam, http://poulwebb.blogspot.com/2013/08/posters-from-stedelijk-museum-amsterdam. html, (accessed in: 12.12.2020), (In English).

URL-5 https://www.benthemcrouwel.com/projects/stedelijk-museum, (accessed in: 02.01.2021), (In English).

URL-6

https://www.volkskrant.nl/kijkverder/v/2019/nog-een-keer-juichen-op-het-museu mplein-en-het-wonderlijke-ajax-jaar-is-voorbij/?referrer=https\%3A\%2F\%2Fwww.g oogle.com\%2F, (accessed in: 22.12.2020), , (In Dutch).

URL-7 Composite Facade Stedelijk Museum Amsterdam, https://www.hollandcomposites.nl/en/portfolio/composite-facade-stedelijk-museum -amsterdam/, (accessed in: 02.01.2021), (In English). 
URL-8 Solıco, www.solico.nl, (accessed in: 06.01.2021), (In English).

Uraz, T. U. 1993. Tasarlama Düşünme Biçimlendirme, İstanbul: İTÜ Mimarlık Fakültesi Yayını

Yıldız, S. (2018) Müze, Saygınlık ve Bir Küvet: Stedelijk Müzesi, Mimarlık, S.403, s.60-66

\section{EXTENDED ABSTRACT}

The concept of form is explained in the Turkish Dictionary prepared by TDK as "the quality of an object in terms of its contours, its external appearance, shape, equals". The words 'form' in English and 'form' in French, which we encounter in the use of the concept in foreign literature, derive from the Latin word 'forme', which includes the meanings of shape, form, appearance, and they have the same meaning. The concept of form, which means "plastic or graphic expression of a certain theme in concrete arts" in architecture, refers to the graphic expression of the subject that the architect wants to convey in the design process.

Form is the order that determines the continuity and boundaries of an architectural object. The subjectivity of the architect, who brings solutions to different problems in shaping, allows this process to be formed with very different methods, orders and approaches.

The basic elements of the forms created depending on the design activity are the mass of the building, the places designed and the surfaces created. While forms reveal what the building is, they can be defined by means of the formal and environmental relations it has in terms of its creation purpose. In the world of architecture, form expresses the organic unity and harmony of all elements from the shape, color and texture perceived as a concept expressing the lines of the spaces and the shell in a building.

There are many factors that play a role in the production of forms that various elements come together in different contexts to create as unique combinations. It is possible to group the factors observed in the formation of the forms of buildings in architecture under four headings. The environmental impacts arising from the region where the architectural structure is located can be summarized as the impacts arising from the thinking system of the architect who takes part in the identity of the designer, the impacts arising from the values system of the society lived in and the inevitably realized technological developments. This study questions which of the factors that affect the shaping exist on the Stedelijk Museum annex.

Stedelijk Museum annex is associated with three of the environmental impacts arising from the region where the architectural structure is located and five of the impacts arising from the thinking system of the architect. It is associated with three of the factors arising from the system of values of the society, and four of the factors related to technological developments.

The main purpose of the formation of the form of the Stedelijk Museum annex was to reveal the difference between two different time periods. While doing this, it is aimed to reflect the identity of the museum to the shell that forms the shape of the smooth white surfaces with the design that forms the combination of the old building and the new annex building in the present. With the form created for this purpose, the place of the building in the city life has been revealed. 